\title{
Design, Synthesis, and Biochemical Evaluation of 1,5,6,7- Tetrahydro-6,7-dioxo-9-D-Ribitylaminolumazines Bearing Alkyl Phosphate Substituents as Inhibitors of Lumazine Synthase and Riboflavin Synthase
}

\author{
Mark Cushman ${ }^{\star}, \dagger$, Guangyi Jin ${ }^{\dagger}$, Boris Illarionov $\ddagger$, Markus Fischer ${ }^{\ddagger}$, Rudolf Ladenstein $\S$, and \\ Adelbert Bacher ${ }^{\ddagger}$ \\ Department of Medicinal Chemistry and Molecular Pharmacology and the Purdue Cancer Center, \\ School of Pharmacy and Pharmaceutical Sciences, Purdue University, West Lafayette, IN 47907, \\ Lehrstuhl für Organische Chemie und Biochemie, Technische Universität München, D-85747 \\ Garching, Germany, and Karolinska Institute, NOVUM Centre for Structural Biochemistry, S-14157 \\ Huddinge, Sweden
}

\section{Abstract}

The last two steps in the biosynthesis of riboflavin, an essential metabolite that is involved in electron transport, are catalyzed by lumazine synthase and riboflavin synthase. In order to obtain structural probes and inhibitors of these two enzymes, two ribityllumazinediones bearing alkyl phosphate substituents were synthesized. The synthesis involved the generation of the ribityl side chain, the phosphate side chain, and the lumazine system in protected form, followed by the simultaneous removal of three different types of protecting groups. The products were designed as intermediate analog inhibitors of lumazine synthase that would bind to its phosphate-binding site as well as its lumazine binding site. Both compounds were found to be effective inhibitors of both Bacillus subtilis lumazine synthase as well as Escherichia coli riboflavin synthase. Molecular modeling of the binding of one of the two compounds provided a structural explanation for how these compounds are able to effectively inhibit both enzymes. In phosphate-free buffer, the phosphate moieties of the inhibitors were found to contribute positively to their binding to Mycobacterium tuberculosis lumazine synthase, resulting in very potent inhibitors with $K_{\mathrm{i}}$ values in the low nanomolar range. The additional carbonyl in the dioxolumazine system vs. the purinetrione system was found to make a positive contribution to its binding to $E$. coli riboflavin synthase.

\section{Introduction}

The last two steps in the biosynthesis of riboflavin (Scheme 1) involve the lumazine synthasecatalyzed reaction of the four-carbon phosphate $\mathbf{2}$ with the ribitylaminopyrimidinedione $\mathbf{1}$ to form 6,7-dimethyl-8-ribitylumazine (3), followed by the riboflavin synthase-catalyzed dismutation of two molecules of $\mathbf{3}$ to form one molecule of riboflavin (4) and one molecule of the lumazine synthase substrate $\mathbf{1}$. In a beautiful example of natural recycling, the product $\mathbf{1}$ of the riboflavin synthase-catalyzed reaction is then utilized by lumazine synthase. The overall stoichiometry involves the consumption of one molecule of the pyrimidinedione $\mathbf{1}$ and two molecules of the organophosphate 2 to form one molecule of riboflavin (4). ${ }^{1-5}$

\footnotetext{
*Corresponding Author. Phone number: 765-494-1465, fax number: 765-494-6790. cushman@ pharmacy.purdue.edu.

†Purdue University

Technische Universität München

§arolinska Institute
} 
The mechanism proposed for the lumazine synthase-catalyzed reaction has gone through several iterations, the most recent of which is outlined in Scheme $2 .^{6}$ The location of the phosphate moiety in the enzyme complex involving the hypothetical intermediate $\mathbf{5}$, relative to the remainder of the molecule, is roughly approximated as shown in the structure of the initial carbinolamine intermediate $\mathbf{5}$ as displayed in Scheme 2, as evidenced by the crystal structure of the complex formed between Saccharomyces cerevisiae lumazine synthase and the intermediate analogue $\mathbf{1 1}^{7}$ (Figure 1). ${ }^{8}$ Rotation of the whole phosphate-containing side chain toward the ribitylamino moiety would then generate conformer $\mathbf{6}$, which could eliminate water to form the cis Schiff base 7. Phosphate elimination would lead to the enol $\mathbf{8}$, followed by tautomerization to the ketone $\mathbf{9}$. Nucleophilic attack of the ribitylamino group on the ketone would result in the carbinolamine 10, which could eliminate water to form the final product 3.

Although the pathway outlined in Scheme 2 seems reasonable from a structural and mechanistic point of view, the exact sequence of the events required to form the final product has not been rigorously established. For example, phosphate elimination could occur after Schiff base formation and before the conformational reorganization of the side chain to favor formation of the six-membered ring. 9

When determined in the presence of fixed substrate $\mathbf{1}$ concentration and variable substrate $\mathbf{2}$ concentration, the phosphonate $\mathbf{1 1}$ is a moderately active inhibitor of $B$. subtilis lumazine synthase (mixed inhibition, $K_{\mathrm{i}} 180 \mu \mathrm{M}, K_{\mathrm{is}} 350 \mu \mathrm{M}$ ). ${ }^{7}$ When tested under the same conditions, the purinetrione 12 proved to be more potent, displaying mixed inhibition with a $K_{\mathrm{i}}$ of $46 \mu \mathrm{M}$ and a $K_{\mathrm{is}}$ of $250 \mu \mathrm{M}$. ${ }^{10}$ The combination of the purinetrione ring system with a C-5 phosphate side chain to form $\mathbf{1 3}$ resulted in a less potent inhibitor of $B$. subtilis lumazine synthase $\left(K_{\mathrm{i}}\right.$, $\left.852 \mu \mathrm{M} ; K_{\mathrm{is}}, 817 \mu \mathrm{M}\right)$ when tested in the presence of variable substrate 2 concentration. 11 However, the substituted purinetrione $\mathbf{1 3}$ unexpectedly proved to be a very potent competitive inhibitor of Mycobacterium tuberculosis lumazine synthase when tested in Tris buffer (phosphate free) with a $K_{\mathrm{i}}$ of $4.7 \mathrm{nM} !^{11}$ The selectivity of this compound and its phosphate homologs for the M. tuberculosis enzyme as opposed to the Bacillus subtilis enzyme is truly remarkable. The alkylphosphonate side chain does in fact contribute positively to inhibition of M. tuberculosis lumazine synthase, since the purinetrione system $\mathbf{1 2}$ itself is a $K_{\mathrm{i}} 9.1 \mu \mathrm{M}$ inhibitor of the enzyme. ${ }^{11}$ The alkylphosphonate derivative $\mathbf{1 3}$ is also a competitive inhibitor of Escherichia coli riboflavin synthase with a $K_{\mathrm{i}}$ of $2.44 \mu \mathrm{M} .^{11}$<smiles>O=c1[nH]c(=O)c2c([nH]c(=O)n2CC(O)C(O)C(O)CO)n(CCCCCCOP(=O)(O)O)c1=O</smiles>

These results suggest consideration of the 6,7-dihydro-6,7-dioxo-8-ribityllumazine system 14, which was previously shown to be an exceedingly potent inhibitor of baker's yeast riboflavin synthase $\left(K_{\mathrm{i}} 25 \mathrm{nM}\right)^{12}$ and Ashbya gossypii riboflavin synthase $\left(K_{\mathrm{i}} 9 \mathrm{nM}\right) .{ }^{13}$ This led to the hypothesis that the attachment of alkylphosphate side chains on N-5 of the 6,7dioxo-8-ribityllumazine (14) system would likely result in promising inhibitors of $E$. coli 
riboflavin synthase as well as $M$. tuberculosis lumazine synthase. The present communication describes the synthesis and biological testing of the suggested five-carbon and six-carbon alkylphosphate derivatives of $\mathbf{1 4}$.<smiles>O=c1[nH]c(=O)c2[nH]c(=O)c(=O)n(C[C@H](O)[C@H](O)[C@H](O)CO)c2[nH]1</smiles>

14

The rationale for the potential medical use of riboflavin synthase inhibitors stems from the fact that certain Gram-negative pathogenic bacteria and yeasts have been shown to lack an efficient riboflavin uptake system and are therefore absolutely dependent on endogenous riboflavin biosynthesis. ${ }^{14-17}$ In contrast, humans lack riboflavin biosynthesis enzymes and obtain this essential nutrient entirely from dietary sources. Therefore, inhibitors of riboflavin biosynthesis can be expected to display selective cytotoxicity for pathogenic microorganisms as opposed to human cells.

\section{Results and Discussion}

The linker from the phosphate to the pyrimidine ring in the proposed reaction intermediate 5 is four atoms long and the results from previous studies on the purinetrione derivative $\mathbf{1 3}$ and its homologues revealed that the best linkers between phosphate and purinetrione ring are from three to five atoms long for inhibition of $M$. tuberculosis lumazine synthase. It was therefore logical to choose the alkylphosphate derivatives of $\mathbf{1 4}$ with polymethylene chains containing four and five carbon atoms. 11,18

The syntheses of the two phosphates $\mathbf{2 1}$ and $\mathbf{2 2}$ having four- and five-methylene linker chains between the phosphate and the lumazinedione ring system are outlined in Scheme 3. Since the lumazinedione ring system $\mathbf{1 4}$ and the ribityl hydroxyl groups can be alkylated, the synthesis required the generation of these two moieties in protected form before the desired alkylation reaction could be carried out. Starting from the known pyrimidine $\mathbf{1 5}^{11}$, catalytic reduction of the nitro group over palladium on carbon yielded an unstable amine intermediate that was reacted immediately with ethyl chlorooxoacetate, followed by heating the intermediate with triethylamine in refluxing ethanol, to provide the pteridine system $\mathbf{1 6}$. Reaction of $\mathbf{1 6}$ with 1,4diiodobutane and 1,5-diiodopentane resulted in displacement of one of the iodides from each diiodo compound to afford the desired alkyl iodides $\mathbf{1 7}$ and $\mathbf{1 8}$. Displacement reactions on the iodides $\mathbf{1 7}$ and $\mathbf{1 8}$ with silver dibenzyl phosphate resulted in the alkyl phosphates $\mathbf{1 9}$ and $\mathbf{2 0 .}$ Simultaneous removal of all three types of protecting groups (TBDMS, methyl, and benzyl) was accomplished by heating intermediates 19 and 20 with $\mathrm{HBr}$ in aqueous methanol at 55$60{ }^{\circ} \mathrm{C}$ to afford the target compounds $\mathbf{2 1}$ and $\mathbf{2 2}$ in good yields.

The phosphates $\mathbf{2 1}$ and $\mathbf{2 2}$ were tested as inhibitors of recombinant $B$. subtilis lumazine synthase $\beta_{60}$ capsids, recombinant $E$. coli riboflavin synthase, and recombinant $M$. tuberculosis lumazine synthase. The inhibition constants and inhibition mechanisms for $\mathbf{2 1}$ and $\mathbf{2 2}$ are listed in Table 1. To evaluate the effect of substitution with the alkylphosphate chains in these 
compounds, the dioxolumazine system 14 itself was also tested as an inhibitor of all three enzymes, and the previously determined data for the purinetriones $\mathbf{2 3}$ and $\mathbf{2 4}$ are also listed in Table 1 for comparison. ${ }^{11}$ Representative Lineweaver-Burke plots for inhibition of $B$. subtilis lumazine synthase, $M$. tuberculosis lumazine synthase, and E. coli riboflavin synthase by inhibitor 22 are presented in Figure 2.<smiles>O=c1[nH]c(=O)n(COP(=O)(O)O)c2[nH]c(=O)n(C[C@H](O)[C@H](O)[C@H](O)CO)c(=O)c12</smiles>

$$
\begin{aligned}
& 23 n=4 \\
& 24 n=5
\end{aligned}
$$

Crystal structures are now available for complexes formed between the substrate analogue 25 and the lumazine synthases of $B$. subtilis and $S$. pombe. ${ }^{19,20}$ The X-ray structure of the intermediate analogue $\mathbf{1 1}$ bound to $S$. cerevisiae lumazine synthase (Figure 1), ${ }^{8}$ the product analogue 26 bound to $S$. pombe lumazine synthase, ${ }^{20}$ and the intermediate analogue inhibitor 23 and its lower homologue bound to $M$. tuberculosis lumazine synthase all allow the rational docking and energy minimization of additional lumazine synthase inhibitors to create hypothetical structures of their enzyme complexes. In the present case, a molecular model was constructed by overlapping the structure of $\mathbf{2 2}$ with that of $\mathbf{2 5}$ in a $15 \AA$ spherical fragment surrounding the ligand in one of the sixty equivalent active sites of B. subtilis lumazine synthase. The structure of $\mathbf{2 5}$ was then deleted and the energy of the complex minimized using the MMFF94s force field and MMFF94 charges while allowing the ligand and the protein structure contained within a $6 \AA$ sphere surrounding the ligand to be flexible and the remainder of the protein structure immobile. The resulting structure is displayed in Figure 3, which shows the bound ligand 22 (red) and the surrounding amino acid residues of the protein that are calculated to be involved in hydrogen bonding (yellow lines) to the ligand. The calculated structure of the complex shows the expected stacking of the lumazinedione ring system of the ligand with the benzene ring of Phe22. There is extensive bonding of the phosphate moiety with the side chain nitrogens of Arg127, the side chain hydroxyl of Thr86, and the backbone nitrogens of Thr86 and Ala85. The imide fragment of the heterocyclic system has contacts with the backbone nitrogen of Ala56, the backbone carbonyl of Thr80, and the side chain nitrogen of Asn23. The side chain nitrogen of Lys135 is calculated to play a strong role in stabilizing the complex, with possible hydrogen bonding contacts with the $\mathrm{C}-7$ carbonyl of the heterocyclic system of the ligand as well as with the 3'- and 4'-hydroxyl groups. A water molecule hydrogen bonds to the 2'-hydroxyl group of the ribityl moiety, and the 4'-hydroxyl group hydrogen bonds to the side chain carbonyl of Phe113'. The 5'-hydroxyl group is calculated to bond to the side chain hydroxy group of Ser142 and the carboxyl of Glu58. All of the calculated hydrogen bonds and distances are displayed in Figure 4. 
<smiles>O=c1[nH]c(NCC(O)[C@H](O)[C@H](O)CO)c([N+](=O)[O-])c(=O)[nH]1</smiles>

25<smiles>C=C1NC(=O)c2nc(CCC(=O)O)c(=O)n(C[C@H](O)[C@H](O)C(O)CO)c2N1</smiles>

New antibiotics that are active against drug-resistant M. tuberculosis are needed urgently. Therefore, the phosphates $\mathbf{2 1}$ and $\mathbf{2 2}$, as well as the parent compound $\mathbf{1 4}$, were tested as inhibitors of $M$ tuberculosis lumazine synthase. Both of the phosphates $21\left(K_{\mathrm{i}} 0.036 \mu \mathrm{M}\right)$ and $22\left(K_{\mathrm{i}} 0.012 \mu \mathrm{M}\right)$, like $\mathbf{2 3}$ and $\mathbf{2 4}$, proved to be very potent inhibitors with $K_{\mathrm{i}}$ values in the low nanomolar range. Interestingly, the attachment of the phosphate chains to the lumazinedione 14 caused a dramatic increase in potency vs. M. tuberculosis lumazine synthase (compare 14 vs. 21 and 22). This is in contrast to the results seen with the $B$. subtilis enzyme, where decreases in potency resulted from side chain attachment when tested in the presence of variable substrate 1 concentration. As with the $B$. subtilis enzyme, the increase in the side chain length resulted in a modest increase in potency vs. M. tuberculosis lumazine synthase (compare $\mathbf{2 1}$ vs. 22). However, both $\mathbf{2 1}$ and $\mathbf{2 2}$ appeared to be slightly less active vs. M. tuberculosis lumazine synthase than $\mathbf{2 3}$ and $\mathbf{2 4}$. All of the compounds tested proved to be competitive inhibitors of M. tuberculosis lumazine synthase.

The purinetrione system 12 can be considered to be a product analog of lumazine synthase and a substrate analog of riboflavin synthase. Accordingly, it was previously tested as an inhibitor of both enzymes and found to be a $K_{\mathrm{i}} 46 \mu \mathrm{M}$ inhibitor of $B$. subtilis lumazine synthase (with variable 2concentration) and a $0.61 \mu \mathrm{M}$ inhibitor of $E$. coli riboflavin synthase. ${ }^{10}$ However, unexpectedly, the phosphate derivatives $\mathbf{2 3}$ and $\mathbf{2 4}$ also proved to be riboflavin synthase inhibitors. ${ }^{11}$ Accordingly, both lumazindione derivatives $\mathbf{2 1}$ and $\mathbf{2 2}$ were tested vs. E. coli riboflavin synthase. Compound $\mathbf{2 1}$ was a mixed inhibitor with $K_{\mathrm{i}} 9.7 \mu \mathrm{M}$ and $K_{\mathrm{is}} 21 \mu \mathrm{M}$, while 22 was a competitive inhibitor with $K_{\mathrm{i}} 0.14 \mu \mathrm{M}$. This documents a significant effect of chain length on potency, and it is similar to the effect seen with the purinetriones $\mathbf{2 3}$ and $\mathbf{2 4}$. However, both of the lumazinedione phosphate derivatives $\mathbf{2 1}$ and $\mathbf{2 2}$ were much less active that the lumazinedione system 14 itself $\left(K_{\mathrm{i}} 0.0062 \mu \mathrm{M}\right)$, so the attachment of the phosphate side chains to these molecules causes a significant drop in potency vs. E. coli riboflavin synthase. One of the reasons for originally conducting this study was to test the hypothesis that the pyrimidinediones $\mathbf{2 1}$ and $\mathbf{2 2}$ would be more potent as riboflavin synthase inhibitors than the purinetriones $\mathbf{2 3}$ and $\mathbf{2 4}$, and the results indicate that they in fact are more potent inhibitors. The additional carbonyl group present in $\mathbf{2 1}$ and $\mathbf{2 2}$ therefore does have a significantly positive effect on the riboflavin synthase enzyme inhibitory activity that is also reflected in the parent compounds $12\left(K_{\mathrm{i}} 0.61 \mu \mathrm{M}\right)$ and $\mathbf{1 4}\left(K_{\mathrm{i}} 0.0062 \mu \mathrm{M}\right)$.

The crystal structure of $E$. coli riboflavin synthase, which contains three identical subunits, has been published along with a hypothetical model of bound substrate $3 .{ }^{21}$ A crystal structure has also been determined of monomeric $S$. pombe riboflavin synthase with bound substrate analogue 26, 22 and an NMR investigation of the structure of the N-terminal domain of riboflavin synthase has also appeared. ${ }^{23}$ The studies have established that the active site of riboflavin synthase is derived from the intermolecular juxtaposition of residues belonging to 
both of the barrels in the C-terminal and $\mathrm{N}$-terminal domains of two subunits, with one substrate molecule bound to each barrel. Thus, structures are available for the trimeric apoenzyme and a ligand-bound monomer, and the structures of the active site can be proposed by combining elements of the two structures. The structures allow the molecular modeling of the complex formed between $E$. coli riboflavin synthase and the inhibitor $\mathbf{2 2}$ using a similar procedure as described for modeling with lumazine synthase, and the result is displayed in Figure 5. The Cbarrel in Figure 5 is colored magenta and the N-barrel is green. The two ligand molecules are stacked with their ribityl side chains pointing in opposite directions, which is consistent with both the known regiochemistry of the riboflavin synthase-catalyzed reaction and the available crystal structures. ${ }^{3}$ This means that the two phosphate side chains must also be pointing in opposite directions. Overall, the structure indicates that riboflavin synthase could in fact accommodate two molecules of the inhibitor $\mathbf{2 2}$ in the active site.

In conclusion, two alkyl phosphate derivatives of the 6,7-dihydro-6,7-dioxo-8-ribityllumazine system were synthesized and found to be inhibitors of $B$. subtilis and $M$. tuberculosis lumazine synthase as well as $E$. coli riboflavin synthase. The possible binding modes of these compounds were investigated through molecular modeling of complexes formed between compound $\mathbf{2 2}$ and both lumazine synthase and riboflavin synthase. Potential antibiotics that inhibit both lumazine synthase and riboflavin synthase would have a potential therapeutic advantage over those that inhibit only one enzyme because microorganisms would have to mutate both enzymes at the same time in order to acquire drug resistance.

\section{Experimental Section}

\section{General}

Melting points were determined in capillary tubes and are uncorrected. Proton nuclear magnetic resonance spectra $\left({ }^{1} \mathrm{H}\right.$ NMR) were determined at $300 \mathrm{MHz}$ or at $500 \mathrm{MHz}$ as noted. Silica gel used for column chromatography was $230-400$ mesh.

\section{8-(2',3',4',5'-tetrakis-t-butyldimethylsilyl-D-ribityl)-5,6,7,8-tetrahydro-2,4-dimethoxy-6,7- dioxopteridine (16)}

The nitro compound $\mathbf{1 5}(4.21 \mathrm{~g}, 5.32 \mathrm{mmol})$ was dissolved in methanol $(150 \mathrm{~mL})$ and palladium on charcoal $(10 \%, 500 \mathrm{mg})$ was added. The reaction mixture was hydrogenated at room temperature and $1 \mathrm{~atm}$ for 3 days. The catalyst was filtered off, the filtrate was concentrated to remove the solvent completely, and the residue was dried well under vacuum. Triethylamine $(2.2 \mathrm{~mL}, 16 \mathrm{mmol})$ and dichloromethane $(30 \mathrm{~mL})$ were added and the reaction mixture was cooled to $0{ }^{\circ} \mathrm{C}$. A solution of ethyl oxalyl chloride $(0.6 \mathrm{~mL}, 5.32 \mathrm{mmol})$ in dichloromethane $(10 \mathrm{~mL})$ was added dropwise and the mixture was stirred overnight at RT. The reaction mixture was washed with water $(2 \times 20 \mathrm{~mL})$, dried with anhydrous $\mathrm{Na}_{2} \mathrm{SO}_{4}$, filtered, and concentrated under vacuum. The residue was dissolved in absolute ethanol $(150 \mathrm{~mL})$ and TEA $(20 \mathrm{~mL})$ and heated at reflux for $72 \mathrm{~h}$. The solvent was removed under reduced pressure and the residue was purified by flash chromatography (silica gel, $50 \mathrm{~g}$, 230-400 mesh), eluting with hexane-ethyl acetate (1:1), to furnish pure $16(1.55 \mathrm{~g}, 36 \%)$ as a foamy solid. ${ }^{1} \mathrm{H} \mathrm{NMR}\left(300 \mathrm{MHz}, \mathrm{CDCl}_{3}\right)$ $\delta 8.52(\mathrm{~s}, 1 \mathrm{H}), 5.05(\mathrm{dd}, J=9.9 \mathrm{~Hz}, J=13.15 \mathrm{~Hz}, 1 \mathrm{H}), 4.47(\mathrm{~d}, J=9.9 \mathrm{~Hz}, 1 \mathrm{H}), 4.38$ (dd, $J=2.49 \mathrm{~Hz}, J=13.1 \mathrm{~Hz}, 1 \mathrm{H}), 4.12(\mathrm{~s}, 3 \mathrm{H}), 4.05(\mathrm{t}, J=2.13 \mathrm{~Hz}, 1 \mathrm{H}), 4.01(\mathrm{~s}, 3 \mathrm{H}), 3.84(\mathrm{~m}$, $1 \mathrm{H}), 3.72(\mathrm{~m}, 1 \mathrm{H}), 3.60(\mathrm{dd}, J=6.03 \mathrm{~Hz}, J=9.64 \mathrm{~Hz}, 1 \mathrm{H}), 0.97(\mathrm{~s}, 9 \mathrm{H}), 0.90(\mathrm{~s}, 9 \mathrm{H}), 0.89$ (s, $9 \mathrm{H}), 0.64$ (s, $9 \mathrm{H}), 0.19$ (s, $3 \mathrm{H}), 0.14(\mathrm{~s}, 3 \mathrm{H}), 0.12$ (s, $9 \mathrm{H}), 0.07$ (s, $3 \mathrm{H}), 0.06$ (s, $3 \mathrm{H})$, -0.02 (s, $3 \mathrm{H}$ ); IR (KBr) 2954, 2957, 1713, 1603, 1472, 1488, 1378, 1254, 1103, $834 \mathrm{~cm}^{-1}$; EIMS $m / z 815\left(\mathrm{MH}^{+}\right)$. Anal. Calcd for $\mathrm{C}_{37} \mathrm{H}_{74} \mathrm{~N}_{4} \mathrm{O}_{4} \mathrm{Si}_{8}: \mathrm{C}, 54.50 ; \mathrm{H}, 9.15 ; \mathrm{N}, 6.87$. Found: $\mathrm{C}$, 54.50; H, 9.16; N, 6.67 . 


\section{8-(2',3',4',5'-Tetrakis-t-butyldimethylsilyl-D-ribityl)-5,6,7,8-tetrahydro-5-(4'-iodobutyl)-2,4- dimethoxy-6,7-dioxopteridine (17)}

Compound 16 (300 mg, $0.37 \mathrm{mmol}$ ) was dissolved in dry $\mathrm{CH}_{3} \mathrm{CN}(20 \mathrm{~mL})$. Anhydrous $\mathrm{K}_{2} \mathrm{CO}_{3}(200 \mathrm{mg}, 1.45 \mathrm{mmol})$ and 1,4-diiodobutane $(0.24 \mathrm{~mL}, 1.84 \mathrm{mmol})$ were added, and the mixture was heated at reflux overnight. The mixture was filtered and the solvent was removed under reduced pressure. The residue was purified by flash chromatography $\left(\mathrm{SiO}_{2}, 230-400\right.$ mesh) (elution: hexane-EtOAc 95:5) to afford pure $17(234 \mathrm{mg}, 63.0 \%)$ as colorless oil. ${ }^{1} \mathrm{H}$ NMR $\left(300 \mathrm{MHz}, \mathrm{CDCl}_{3}\right) \delta 5.08(\mathrm{dd}, J=10.09 \mathrm{~Hz}, J=13.06 \mathrm{~Hz}, 1 \mathrm{H}), 4.42(\mathrm{~d}, J=9.79 \mathrm{~Hz}$, $1 \mathrm{H}), 4.34(\mathrm{t}, J=9.41 \mathrm{~Hz}, 3 \mathrm{H}), 4.09(\mathrm{~s}, 3 \mathrm{H}), 4.07(\mathrm{~d}, J=13.3 \mathrm{~Hz}, 1 \mathrm{H}), 3.98(\mathrm{~s}, 3 \mathrm{H}), 3.84(\mathrm{t}$, $J=6.48 \mathrm{~Hz}, 1 \mathrm{H}), 3.69(\mathrm{dd}, J=7.23 \mathrm{~Hz}, J=17.95 \mathrm{~Hz}, 1 \mathrm{H}), 3.58(\mathrm{dd}, J=6.03 \mathrm{~Hz}, J=10.56$ $\mathrm{Hz}, 1 \mathrm{H}$ ), $3.21(\mathrm{t}, J=6.46 \mathrm{~Hz}, 2 \mathrm{H}$ ), 1.88 (quint, $J=7.21 \mathrm{~Hz}, 2 \mathrm{H}$ ), 1.82 (quint, $J=7.21 \mathrm{~Hz}, 2$ H), $0.94(\mathrm{~s}, 9 \mathrm{H}), 0.87(\mathrm{~s}, 9 \mathrm{H}), 0.86(\mathrm{~s}, 9 \mathrm{H}), 0.62(\mathrm{~s}, 9 \mathrm{H}), 0.16(\mathrm{~s}, 3 \mathrm{H}), 0.12(\mathrm{~s}, 3 \mathrm{H}), 0.09$ (s, $6 \mathrm{H}), 0.043$ (s, $3 \mathrm{H}), 0.036$ (s, $3 \mathrm{H}),-0.055$ (s, $3 \mathrm{H}),-0.49$ (s, $3 \mathrm{H})$. EIMS m/z $997\left(\mathrm{MH}^{+}\right)$. Anal. Calcd for $\mathrm{C}_{41} \mathrm{H}_{81} \mathrm{IN}_{4} \mathrm{O}_{8} \mathrm{Si}_{4}: \mathrm{C}, 49.37 ; \mathrm{H}, 8.19 ; \mathrm{N}, 5.62$. Found: $\mathrm{C}, 49.21 ; \mathrm{H}, 8.38 ; \mathrm{N}$, 5.27 .

\section{8-(2',3',4',5'-Tetrakis-t-butyldimethylsilyl-D-ribityl)-5,6,7,8-tetrahydro-5-(5'-iodopentyl)-2,4- dimethoxy-6,7-dioxopteridine (18)}

Compound 16 ( $250 \mathrm{mg}, 0.31 \mathrm{mmol})$ was dissolved in dry $\mathrm{CH}_{3} \mathrm{CN}(10 \mathrm{~mL})$. Anhydrous $\mathrm{K}_{2} \mathrm{CO}_{3}(200 \mathrm{mg}, 1.45 \mathrm{mmol})$ and 1,5-diiodopropane $(0.24 \mathrm{~mL}, 1.53 \mathrm{mmol})$ were added, and the mixture was heated at reflux overnight. The mixture was filtered and the solvent was removed under reduced pressure. The residue was purified by flash chromatography $\left(\mathrm{SiO}_{2}\right.$, 230-400 mesh) (elution: hexane-EtOAc 95:5) to afford pure $\mathbf{1 8}(211 \mathrm{mg}, 68.0 \%)$ as a colorless oil. ${ }^{1} \mathrm{H}$ NMR $\left(500 \mathrm{MHz}, \mathrm{CDCl}_{3}\right) \delta 5.08(\mathrm{dd}, J=10.14$ and $13.01 \mathrm{~Hz}, 1 \mathrm{H}), 4.42(\mathrm{~d}, J=9.78$ $\mathrm{Hz}, 1 \mathrm{H}), 4.31$ (t, $J=9.41 \mathrm{~Hz}, 3 \mathrm{H}), 4.08(\mathrm{~s}, 3 \mathrm{H}), 4.05(\mathrm{~d}, J=11.0 \mathrm{~Hz}, 1 \mathrm{H}), 3.98(\mathrm{~s}, 3 \mathrm{H}), 3.84$ (t, $J=5.9 \mathrm{~Hz}, 1 \mathrm{H}), 3.69(\mathrm{dd}, J=7.23$ and $17.95 \mathrm{~Hz}, 1 \mathrm{H}), 3.58(\mathrm{dd}, J=6.06$ and $10.56 \mathrm{~Hz}, 1$ $\mathrm{H}$ ), $3.18(\mathrm{t}, J=6.82 \mathrm{~Hz}, 2 \mathrm{H}$ ), 1.85 (quint, $J=7.21 \mathrm{~Hz}, 2 \mathrm{H}$ ), 1.69 (quint, $J=7.21 \mathrm{~Hz}, 2 \mathrm{H}$ ), 1.48 (quint, $J=7.21 \mathrm{~Hz}, 2 \mathrm{H}), 0.94(\mathrm{~s}, 9 \mathrm{H}), 0.87(\mathrm{~s}, 9 \mathrm{H}), 0.86(\mathrm{~s}, 9 \mathrm{H}), 0.62(\mathrm{~s}, 9 \mathrm{H}), 0.16$ (s, $3 \mathrm{H}), 0.12$ (s, $3 \mathrm{H}), 0.09$ (s, $6 \mathrm{H}), 0.043$ (s, $3 \mathrm{H}), 0.036$ (s, $3 \mathrm{H}),-0.057$ (s, $3 \mathrm{H}),-0.49$ (s, $3 \mathrm{H}$ ); EIMS $\mathrm{m} / z 1011\left(\mathrm{MH}^{+}\right)$. Anal. Calcd for $\mathrm{C}_{42} \mathrm{H}_{83} \mathrm{IN}_{4} \mathrm{O}_{8} \mathrm{Si}_{4}: \mathrm{C}, 49.88 ; \mathrm{H}, 8.27 ; \mathrm{N}, 5.54$. Found: C, 49.79; H, 7.85; N, 5.46.

\section{Dibenzyl 4-[8-(2',3',4',5'-Tetrakis-t-butyldimethylsilyl-D-ribityl)-5,6,7,8-tetrahydro-2,4- dimethoxy-6,7-dioxopterid-5-yl]butane 1-Phosphate (19)}

Compound $17(0.10 \mathrm{~g}, 0.10 \mathrm{mmol})$ and silver dibenzyl phosphate $(0.06 \mathrm{~g}, 0.15 \mathrm{mmol})$ were heated at reflux in dry $\mathrm{CH}_{3} \mathrm{CN}(5.0 \mathrm{~mL})$ for $10 \mathrm{~h}$. The solution was then filtered and concentrated under reduced pressure. The resulting oil was purified by silica gel flash chromatography $\left(\mathrm{SiO}_{2}, 230-400\right.$ mesh) eluting with hexane-ethyl acetate (1:1), to furnish the desired compound $19(0.08 \mathrm{~g}, 70 \%)$ as a colorless oil. ${ }^{1} \mathrm{H} \mathrm{NMR}\left(300 \mathrm{MHz}, \mathrm{CDCl}_{3}\right) \delta 7.31(\mathrm{~s}$, $10 \mathrm{H}), 5.07(\mathrm{dd}, J=10.09$ and $13.06 \mathrm{~Hz}, 1 \mathrm{H}), 4.99(\mathrm{~m}, 4 \mathrm{H}), 4.41(\mathrm{~d}, J=9.41 \mathrm{~Hz}, 1 \mathrm{H}), 4.33$ $(\mathrm{d}, J=13.15 \mathrm{~Hz}, 1 \mathrm{H}), 4.26(\mathrm{t}, J=6.75 \mathrm{~Hz}, 2 \mathrm{H}), 3.99(\mathrm{q}, J=6.04 \mathrm{~Hz}, 2 \mathrm{H}), 3.98(\mathrm{~s}, 3 \mathrm{H}), 3.97$ $(\mathrm{s}, 3 \mathrm{H}), 3.83(\mathrm{t}, J=6.45 \mathrm{~Hz}, 1 \mathrm{H}), 3.68(\mathrm{t}, J=8.82 \mathrm{~Hz}, 1 \mathrm{H}), 3.57(\mathrm{dd}, J=5.99$ and $10.33 \mathrm{~Hz}$, $1 \mathrm{H}), 1.67-1.66(\mathrm{~m}, 4 \mathrm{H}), 0.93(\mathrm{~s}, 9 \mathrm{H}), 0.87$ (s, $9 \mathrm{H}), 0.86(\mathrm{~s}, 9 \mathrm{H}), 0.60$ (s, $9 \mathrm{H}), 0.15$ (s, $3 \mathrm{H})$, 0.11 (s, $3 \mathrm{H}), 0.087$ (s, $6 \mathrm{H}), 0.038$ (s, $3 \mathrm{H}), 0.032$ (s, $3 \mathrm{H}),-0.07$ (s, $3 \mathrm{H}),-0.52$ (s, $3 \mathrm{H})$; EIMS $\mathrm{m} / z 1147\left(\mathrm{MH}^{+}\right)$. Anal. Calcd for $\mathrm{C}_{55} \mathrm{H}_{95} \mathrm{~N}_{4} \mathrm{O}_{12} \mathrm{PSi}_{4}: \mathrm{C}, 57.56 ; \mathrm{H}, 8.34 ; \mathrm{N}, 4.88$. Found: $\mathrm{C}$, $57.33 ; \mathrm{H}, 8.40 ; \mathrm{N}, 5.28$.

\section{Dibenzyl 4-[8-(2',3',4',5'-Tetrakis-t-butyldimethylsilyl-D-ribityl)5,6,7,8-tetrahydro-2,4- dimethoxy - 6, 7 - dioxopterid - 5-yl] pentane 1 - Phosphate (20)}

Compound $18(0.21 \mathrm{~g}, 0.21 \mathrm{mmol})$ and silver dibenzyl phosphate $(0.12 \mathrm{~g}, 0.31 \mathrm{mmol})$ were heated at reflux in dry $\mathrm{CH}_{3} \mathrm{CN}(10 \mathrm{~mL})$ for $10 \mathrm{~h}$. The solution was then filtered and concentrated 
under reduced pressure. The resulting oil was purified by using silica gel flash chromatography $\left(\mathrm{SiO}_{2}, 230-400 \mathrm{mesh}\right)$, eluting with hexane-ethyl acetate (1:1), to furnish the desired compound $20(0.17 \mathrm{~g}, 71 \%)$ as colorless oil. ${ }^{1} \mathrm{H}$ NMR $\left(300 \mathrm{MHz}, \mathrm{CDCl}_{3}\right) \delta 7.32(\mathrm{~s}, 10 \mathrm{H}), 5.08(\mathrm{dd}, J=$ 10.07 and $13.06 \mathrm{~Hz}, 1 \mathrm{H}), 5.01(\mathrm{~m}, 4 \mathrm{H}), 4.41(\mathrm{~d}, J=9.87 \mathrm{~Hz}, 1 \mathrm{H}), 4.33(\mathrm{~d}, J=13.17 \mathrm{~Hz}, 1$ H), $4.25(\mathrm{t}, J=7.72 \mathrm{~Hz}, 2 \mathrm{H}), 4.00(\mathrm{~s}, 3 \mathrm{H}), 3.97(\mathrm{q}, J=6.04 \mathrm{~Hz}, 2 \mathrm{H}), 3.96(\mathrm{~s}, 3 \mathrm{H}), 3.84(\mathrm{t}$, $J=5.79 \mathrm{~Hz}, 1 \mathrm{H}), 3.69(\mathrm{t}, J=8.82 \mathrm{~Hz}, 1 \mathrm{H}), 3.58(\mathrm{dd}, J=5.99$ and $10.33 \mathrm{~Hz}, 1 \mathrm{H}), 1.65-1.63$ $(\mathrm{m}, 4 \mathrm{H}), 1.53(\mathrm{~m}, 2 \mathrm{H}), 0.94(\mathrm{~s}, 9 \mathrm{H}), 0.87(\mathrm{~s}, 9 \mathrm{H}), 0.86(\mathrm{~s}, 9 \mathrm{H}), 0.61(\mathrm{~s}, 9 \mathrm{H}), 0.16(\mathrm{~s}, 3 \mathrm{H})$, 0.11 (s, $3 \mathrm{H}), 0.092$ (s, $6 \mathrm{H}), 0.043$ (s, $3 \mathrm{H}), 0.038$ (s, $3 \mathrm{H}),-0.061$ (s, $3 \mathrm{H}),-0.51$ (s, $3 \mathrm{H})$; EIMS m/z, $1161\left(\mathrm{MH}^{+}\right)$. Anal. Calcd for $\mathrm{C}_{56} \mathrm{H}_{97} \mathrm{~N}_{4} \mathrm{O}_{12} \mathrm{PSi}_{4}$ : C, 57.93; H, 8.36; N, 4.82. Found: C, 57.79; H, 8.06; N, 4.84.

\section{4-(1,5,6,7-Tetrahydro-6,7-dioxo-8-D-ribityllumazin-5-yl)butane 1-Phosphate (21)}

Compound $19(82 \mathrm{mg}, 0.07 \mathrm{mmol})$ was dissolved in a solution of [48\% $\left.\mathrm{HBr}-\mathrm{H}_{2} \mathrm{O}(2: 1)\right]-\mathrm{MeOH}$ $(1: 1 ; 5 \mathrm{~mL})$ and the mixture was stirred at $55-60{ }^{\circ} \mathrm{C}$ for $3 \mathrm{~h}$. The solvent was removed in vacuo, the residue was dissolved in $\mathrm{MeOH}(1 \mathrm{~mL})$, and ethyl ether $(5 \mathrm{~mL})$ was added. After $24 \mathrm{~h}$ in the refrigerator, the precipitate was filtered out as a white solid, which was dissolved in water $(5 \mathrm{~mL})$, decolorized with active charcoal and filtered. The colorless filtrate was lyophilized to furnish 21 (25 mg, 73\%) as a white, highly hygroscopic amorphous solid. ${ }^{1} \mathrm{H}$ NMR $\left(\mathrm{D}_{2} \mathrm{O}\right)(300 \mathrm{MHz}) \delta 3.41-4.27(\mathrm{~m}, 11 \mathrm{H}), 1.45(\mathrm{~m}, 4 \mathrm{H}) ;{ }^{13} \mathrm{C}$ NMR $\left(\mathrm{D}_{2} \mathrm{O}\right)(75 \mathrm{MHz}) \delta$ 158.7, 156.7, 154.5, 149.9, 137.8, 100.6, 76.4, 73.0, 72.4, 71.6, 70.1, 49.2, 45.8, 26.2, 24.9; ESIMS (negative ion mode) $\mathrm{m} / z 481\left[\left(\mathrm{M}-\mathrm{H}^{+}\right)^{-}\right]$. Anal. Calcd for $\mathrm{C}_{15} \mathrm{H}_{23} \mathrm{~N}_{4} \mathrm{O}_{12} \mathrm{P} .0 .6 \mathrm{H}_{2} \mathrm{O}: \mathrm{C}$, 36.50; H, 4.91; N, 11.35. Found: C, 36.84; H, 4.71; N, 10.92.

\section{5-(1,5,6,7-Tetrahydro-6,7-dioxo-8-D-ribityllumazin-5-yl)pentane 1-Phosphate (22)}

This compound was prepared from $\mathbf{2 0}$ in $\mathbf{7 8 \%}$ yield using the procedure above to afford the product as a white, highly hygroscopic amorphous solid (38 mg, 78\%). ${ }^{1} \mathrm{H}$ NMR $\left(\mathrm{D}_{2} \mathrm{O}\right)(300$ MHz) $\delta 3.64-4.58(\mathrm{~m}, 11 \mathrm{H}), 1.75(\mathrm{~m}, 4 \mathrm{H}), 1.52(\mathrm{~m}, 2 \mathrm{H}) ;{ }^{13} \mathrm{C}$ NMR $\left(\mathrm{D}_{2} \mathrm{O}\right)(75 \mathrm{MHz}) \delta 158.7$, 156.8, 154.5, 150.0, 137.9, 100.6, 73.0, 72.4, 70.1, 66.6, 62.8, 47.0, 46.1, 29.6, 27.9, 22.4; ESIMS $m / z 495\left[\left(\mathrm{M}-\mathrm{H}^{+}\right)^{-}\right]$. Anal. Calcd for $\mathrm{C}_{16} \mathrm{H}_{25} \mathrm{~N}_{4} \mathrm{O}_{12} \mathrm{P} .0 .5 \mathrm{H}_{2} \mathrm{O}: \mathrm{C}, 37.99 ; \mathrm{H}, 5.14 ; \mathrm{N}$, 11.08. Found: C, 37.98; H, 4.85; N, 10.73 .

\section{Molecular Modeling on Lumazine Synthase}

Using Sybyl (Tripos, Inc., version 7.0, 2004), the X-ray crystal structure of the complex of 5nitro-6-ribitylamino-2,4-(1H,3H)pyrimidinedione (25) and the lumazine synthase of $B$. subtilis (1RVV) ${ }^{19}$ was clipped to include information within a $15 \AA$-radius of one of the 60 equivalent ligand molecules. The residues that were clipped in this cut complex were capped with either neutral amino or carboxyl groups. The structure of the inhibitor $\mathbf{2 2}$ was overlapped with the structure of 5-nitro-6-ribitylamino-2,4-(1H,3H)pyrimidinedione (25), which was then deleted. Hydrogen atoms were added to the complex. MMFF94 charges were loaded, and the energy of the complex was minimized using the Powell method to a termination gradient of $0.05 \mathrm{kcal} / \mathrm{mol}$ while employing the MMFF94s force field. During the minimization of the complex, inhibitor 22 and $6 \AA$ sphere surrounding it were allowed to remain flexible, while the remaining portion of the complex was held ridged using the aggregate function. Figure 3 was constructed by displaying the amino acid residues of the enzyme that are involved in hydrogen bonding with the inhibitor 22 .

\section{Molecular Modeling on Riboflavin Synthase}

Using Sybyl (Tripos, Inc., version 7.0, 2004), the X-ray crystal structure of E. coli riboflavin synthase (1I8D) was downloaded and two molecules of the ligand 22 were docked and oriented as suggested by the published model of the binding of two molecules of the substrate $\mathbf{1}$ in the active site, ${ }^{21}$ as well as by the structure of $\mathbf{2 2}$ bound to $S$. pombe riboflavin synthase. ${ }^{22}$ The 
$\mathrm{C}$ - and $\mathrm{N}$-terminal groups were changed to neutral carboxylic acid and amino groups, and hydrogens were added to the protein structure and to the oxygens of the water molecules. MMFF94 charges were loaded, and the energy of a $6 \AA$-radius spherical subset including and surrounding the two ligand molecules was minimized using the Powell method to a termination gradient of $0.05 \mathrm{kcal} / \mathrm{mol}$ while employing the MMFF94s force field. During energy minimization, the remaining protein structure was held rigid using the aggregate function. Figure 5 was constructed by displaying the amino acid residues in the C- and N-barrels surrounding the two ligand molecules.

\section{Lumazine Synthase Assay. 24}

The experiments with $B$. subtilis lumazine synthase were performed as follows. Reaction mixtures contained $100 \mathrm{mM}$ potassium phosphate, $\mathrm{pH}$ 7.0, $5 \mathrm{mM}$ EDTA, $5 \mathrm{mM}$ dithiothreitol, inhibitor (0-500 $\mu \mathrm{M}), 150 \mu \mathrm{M}$ L-3,4-hihydroxy-2-butanone phosphate (2) and B. subtilis lumazine synthase ( $7 \mu \mathrm{g}$, specific activity $\left.12.8 \mu \mathrm{mol} \mathrm{mg}^{-1} \mathrm{~h}^{-1}\right)$ in a total volume of $1000 \mu \mathrm{L}$. The solution was incubated at $37{ }^{\circ} \mathrm{C}$, and the reaction was started by the addition of a small volume $(20 \mu \mathrm{L})$ of 5-amino-6-ribitylamino-2,4 $(1 H, 3 H)$-pyrimidinedione (1) to a final concentration of 5-100 $\mu \mathrm{M}$. The experiments with $M$. tuberculosis lumazine synthase were conducted as follows. Reaction mixtures contained $50 \mathrm{mM}$ Tris hydrochloride, $\mathrm{pH}$ 7.0, 100 $\mathrm{mM} \mathrm{NaCl}, 5 \mathrm{mM}$ EDTA, $5 \mathrm{mM}$ dithiothreitol, $150 \mu \mathrm{M} \mathrm{L}$-3,4-hihydroxy-2-butanone phosphate (2) inhibitor $(0-500 \mu \mathrm{M})$ and $M$. tuberculosis enzyme (12.5 $\mu \mathrm{g}$, specific activity $4.3 \mu \mathrm{mol}$ $\mathrm{mg}^{-1} \mathrm{~h}^{-1}$ ) in a total volume of $1000 \mu \mathrm{L}$. The mixtures were incubated at $37^{\circ} \mathrm{C}$, and the reaction was started by the addition of a small volume $(20 \mu \mathrm{L})$ of substrate 1 to a final concentration of 20-400 $\mu \mathrm{M}$. The formation of 6,7-dimethyl-8-ribityllumazine (3) was measured online with a computer controlled photometer at $408 \mathrm{~nm}\left(\varepsilon_{\text {Lumazine }}=10200 \mathrm{M}^{-1} \mathrm{~cm}^{-1}\right)$. The velocitysubstrate data were fitted for all inhibitor concentrations with a non- linear regression method using the program DynaFit ${ }^{\mathrm{TM}} 25$ Different inhibition models were considered for the calculation. $K_{\mathrm{i}}$ and $K_{\mathrm{is}}$ values \pm standard deviations were obtained from the fit under consideration of the most likely inhibition model.

\section{Riboflavin Synthase Assay. 26}

Reaction mixtures contained buffer (100 mM potassium phosphate, $\mathrm{pH}$ 7.0, $10 \mathrm{mM}$ EDTA, 10 $\mathrm{mM}$ sodium sulfite), inhibitor ( 0 to $300 \mu \mathrm{M})$, and riboflavin synthase ( $1.2 \mu \mathrm{g}$, specific activity $\left.45 \mu \mathrm{mol} \mathrm{mg}{ }^{-1} \mathrm{~h}^{-1}\right)$. After preincubation, the reactions were started by the addition of various amounts of 6,7-dimethyl-8-ribityllumazine (3) $(2.5$ to $200 \mu \mathrm{M})$ to a total volume of $1000 \mu \mathrm{L}$. The formation of riboflavin (4) was measured online with a computer controlled photometer at $470 \mathrm{~nm}\left(\varepsilon_{\text {Riboflavin }}=9600 \mathrm{M}^{-1} \mathrm{~cm}^{-1}\right)$. The evaluation of data sets was performed in the same manner as described above.

\section{Acknowledgements}

This research was made possible by NIH grant GM51469 as well as by support from the Deutsche Forschungsgemeinschaft, the Fonds der Chemischen Industrie and the Hans Fischer Gesellschaft e. V.

\section{References}

1. Plaut GWE, Smith CM, Alworth WL. Ann Rev Biochem 1974;43:899-922. [PubMed: 4368458]

2. Plaut, GWE. Comprehensive Biochemistry. Florkin, M.; Stotz, EH., editors. 21. Elsevier; Amsterdam: 1971. p. 11-45.

3. Beach RL, Plaut GWE. J Am Chem Soc 1970;92:2913-2916. [PubMed: 5439976]

4. Bacher, A.; Eberhardt, S.; Richter, G. Escherichia coli and Salmonella: Cellular and Molecular Biology. 2. Neidhardt, FC., editor. ASM Press; Washington, D. C: 1996. p. 657-664. 
5. Bacher A, Fischer M, Kis K, Kugelbrey K, Mörtl S, Scheuring J, Weinkauf S, Eberhardt S, SchmidtBäse K, Huber R, Ritsert K, Cushman M, Ladenstein R. Biochem Soc Trans 1996;24:89-94. [PubMed: 8674771]

6. Zhang X, Meining W, Cushman M, Haase I, Fischer M, Bacher A, Ladenstein R. J Mol Biol 2003;328:167-182. [PubMed: 12684006]

7. Cushman M, Mihalic JT, Kis K, Bacher A. J Org Chem 1999;64:3838-3845.

8. Meining W, Mörtl S, Fischer M, Cushman M, Bacher A, Ladenstein R. J Mol Biol 2000;299:181-197. [PubMed: 10860731]

9. Volk R, Bacher A. J Am Chem Soc 1988;110:3651-3653.

10. Cushman M, Yang D, Kis K, Bacher A. J Org Chem 2001;66:8320-8327. [PubMed: 11735509]

11. Cushman M, Sambaiah T, Jin G, Illarionov B, Fischer M, Bacher A. J Org Chem 2004;69:601-612. [PubMed: 14750781]

12. Al-Hassan SS, Kulick RJ, Livingston DB, Suckling CJ, Wood HCS, Wrigglesworth R, Ferone R. J Chem Soc, Perkin Trans 1;1980:2645-2656.

13. Winestock CH, Aogaichi T, Plaut GWE. J Biol Chem 1963;238:2866-2874. [PubMed: 14063316]

14. Wang A. I Chuan Hsueh Pao 1992;19:362-368. [PubMed: 1466913]

15. Oltmanns O, Lingens F. Z Naturforschung 1967;22:751-754.

16. Logvinenko EM, Shavlovsky GM. Mikrobiologiya 1967;41:978-979.

17. Neuberger G, Bacher A. Biochem Biophys Res Commun 1985;127:175-181. [PubMed: 3838473]

18. Morgunova K, Meining W, Illarionov B, Haase I, Jin G, Bacher A, Cushman M, Fischer M, Ladenstein R. Biochemistry 2005;44:2746-2758. [PubMed: 15723519]

19. Ritsert K, Huber R, Turk D, Ladenstein R, Schmidt-Bäse K, Bacher A. J Mol Biol 1995;253:151167. [PubMed: 7473709]

20. Gerhardt S, Haase I, Steinbacher S, Kaiser JT, Cushman M, Bacher A, Huber R, Fischer M. J Mol Biol 2002;318:1317-1329. [PubMed: 12083520]

21. Liao DI, Wawrzak Z, Calabrese JC, Viitanen PV, Jordan DB. Structure 2001;9:399-408. [PubMed: 11377200]

22. Gerhardt S, Schott AK, Kairies N, Cushman M, Illarionov B, Eisenreich W, Bacher A, Huber R, Steinbacher S, Fischer M. Structure 2002;10:1371-1381. [PubMed: 12377123]

23. Truffault V, Coles M, Diericks T, Abelmann K, Eberhardt S, Lüttgen H, Bacher A, Kessler H. J Mol Biol 2001;309:949-960. [PubMed: 11399071]

24. Kis K, Bacher A. J Biol Chem 1995;270:16788-16795. [PubMed: 7622491]

25. Kuzmic P. Anal Biochem 1996;237:260-273. [PubMed: 8660575]

26. Eberhardt S, Richter G, Gimbel W, Werner T, Bacher A. Eur J Biochem 1996;242:712-718. [PubMed: 9022701] 

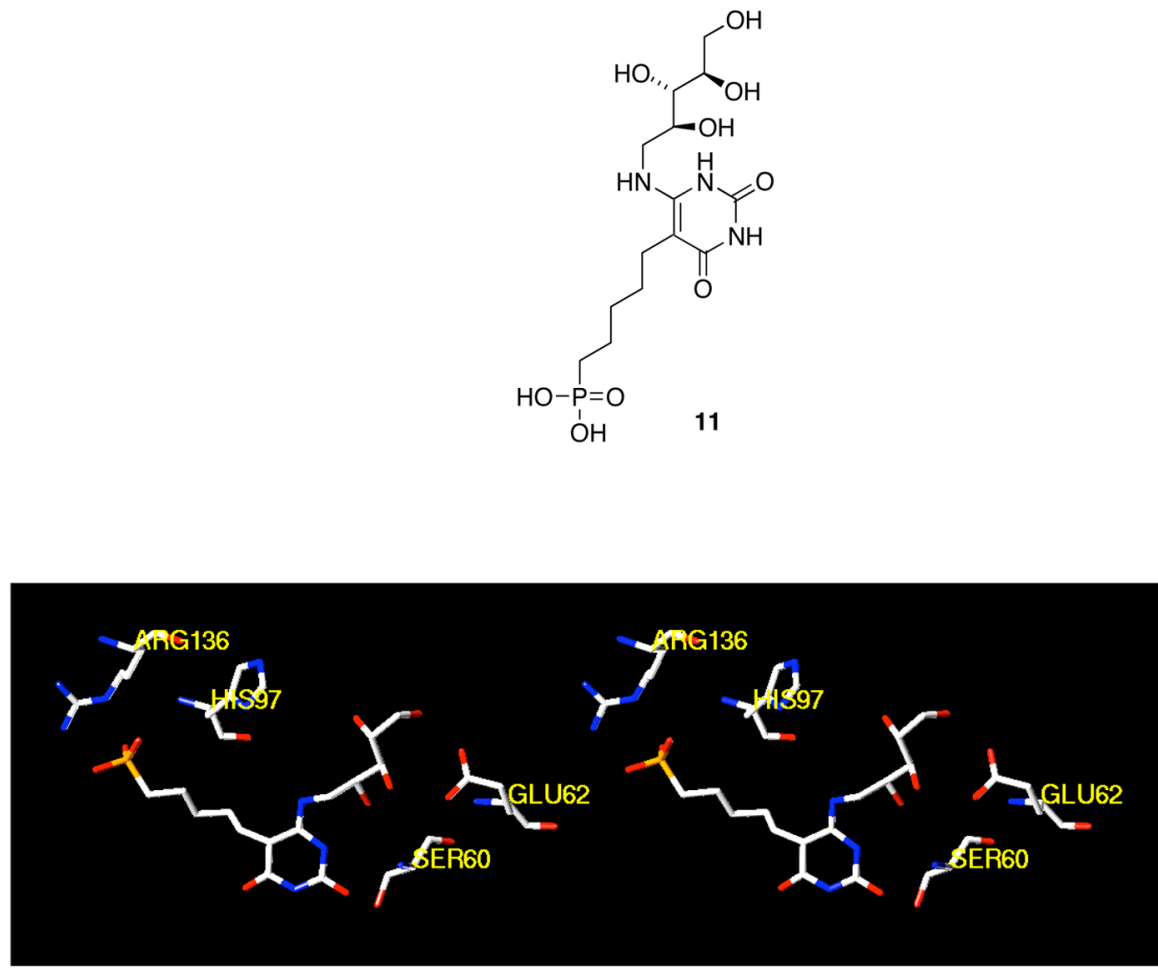

Figure 1.

Crystal structure of phosphonate $\mathbf{1 1}$ bound in the active site of S. cerevisiae lumazine synthase. 8 The figure is programmed for walleyed viewing. 

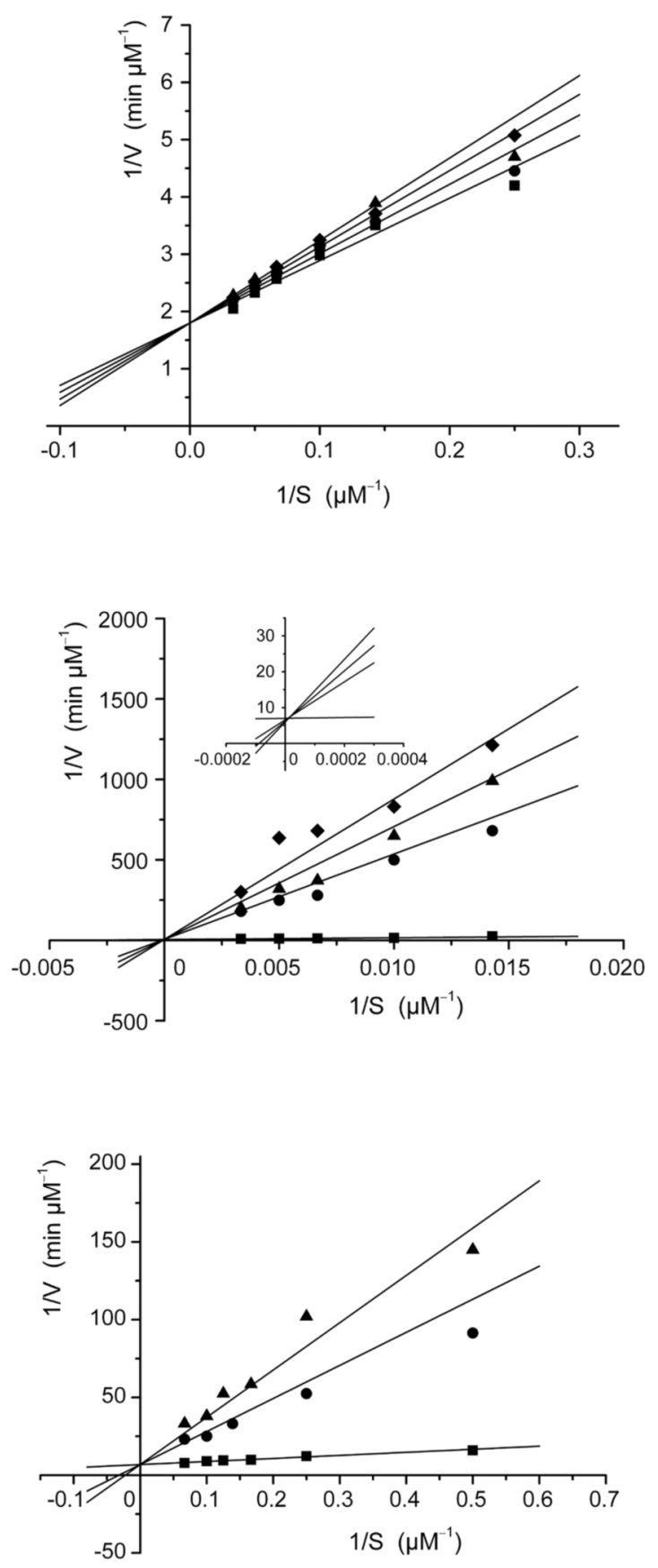

Figure 2.

Lineweaver-Burke plots for the inhibition of $B$. subtilis lumazine synthase by inhibitor 22 (top: inhibitor concentrations $0,3.0,6.0$, and $8.6 \mu \mathrm{M}$, mechanism: competitive), M. tuberculosis lumazine synthase (center: inhibitor concentrations $0,0.8,1.0$, and $1.2 \mu \mathrm{M}$, mechanism: competitive), and E. coli riboflavin synthase (bottom: inhibitor concentrations $0,1.5$, and 2.0 $\mu \mathrm{M}$, mechanism: competitive). The inset in the $M$. tuberculosis plot (middle) shows an expanded view of the simulation plot in the region $1 / \mathrm{S}=0$. The kinetic data were fitted with a nonlinear regression method using the program Dynafit from P. Kuzmic (1996). Different kinetic models were considered, and the most likely inhibition mechanism was determined to be competitive inhibition in each case. 


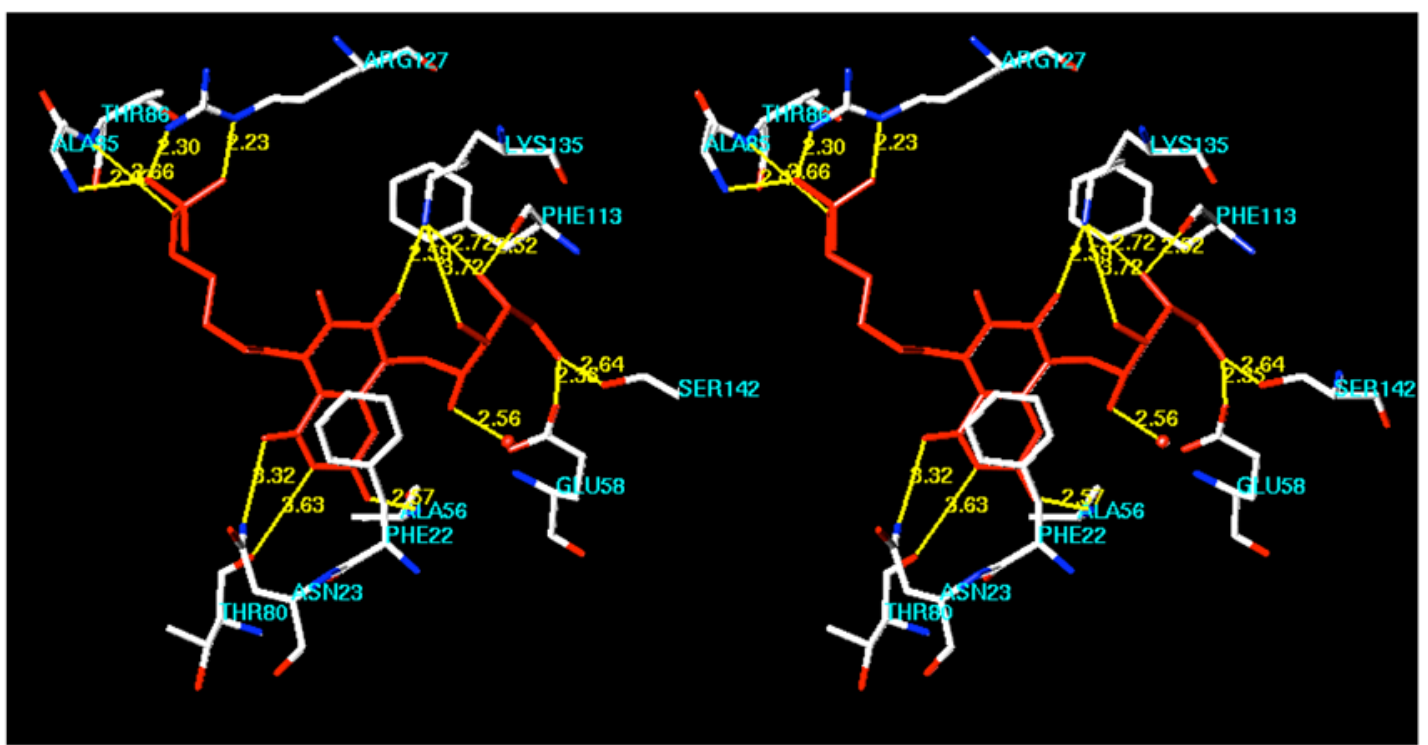

Figure 3.

Hypothetical model for the binding of compound $\mathbf{2 2}$ to Bacillus subtilis lumazine synthase. The figure is programmed for walleyed viewing. 


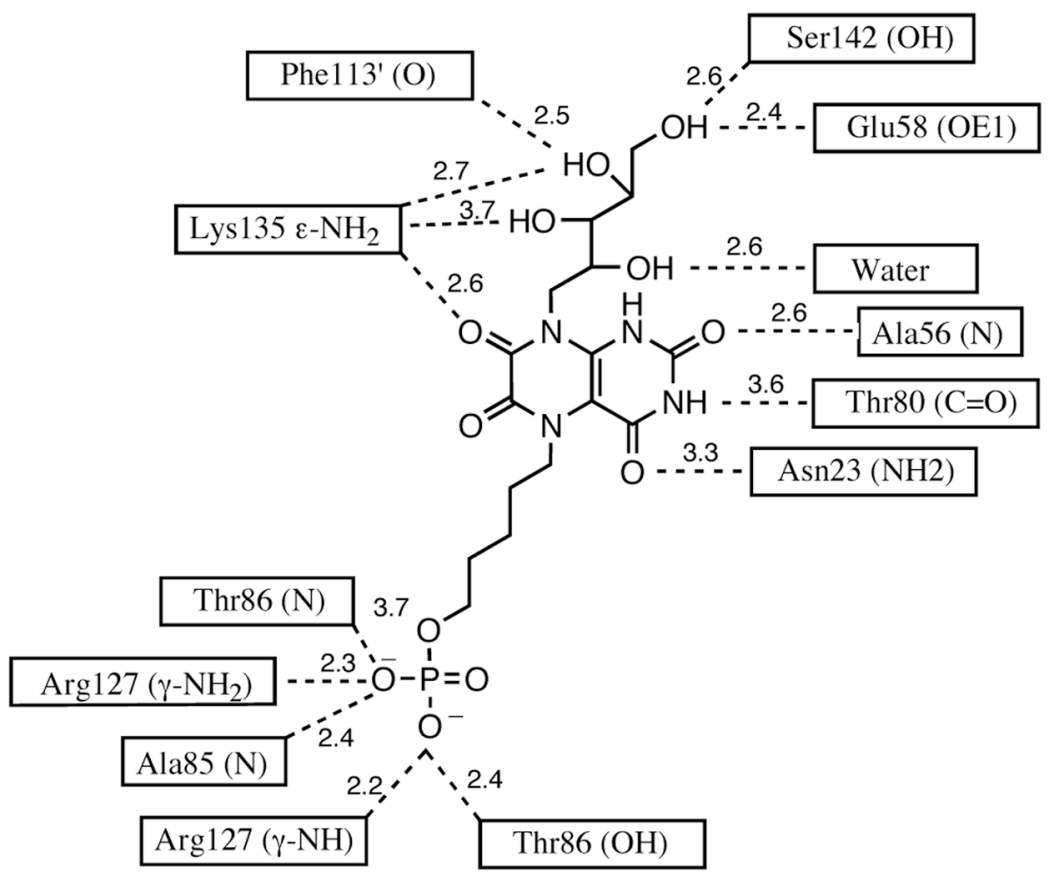

Figure 4.

Hydrogen bonds and distances in the calculated model of the inhibitor $\mathbf{2 2}$ bound in the active site of $B$. subtilis lumazine synthase. 


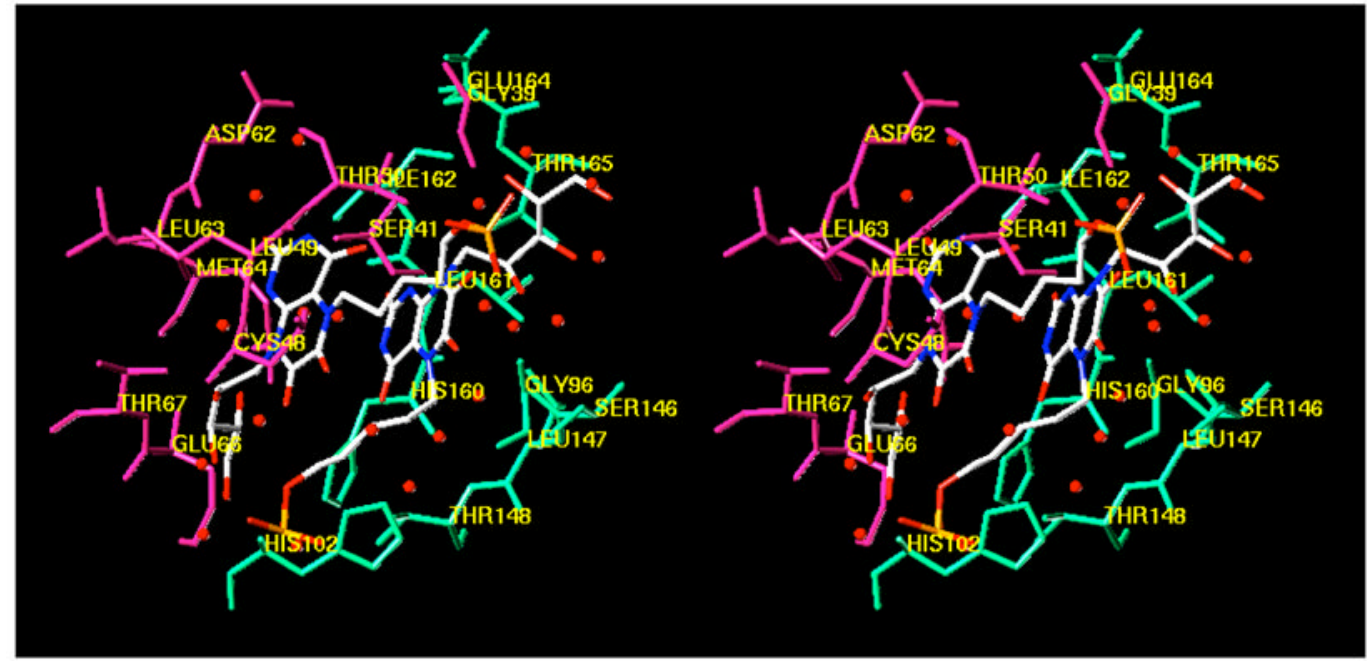

Figure 5.

Hypothetical model of the binding of two molecules of inhibitor $\mathbf{2 2}$ to $E$. coli riboflavin synthase. The C-barrel is magenta and the $\mathrm{N}$-barrel is green. The model is programmed for walleyed viewing. 


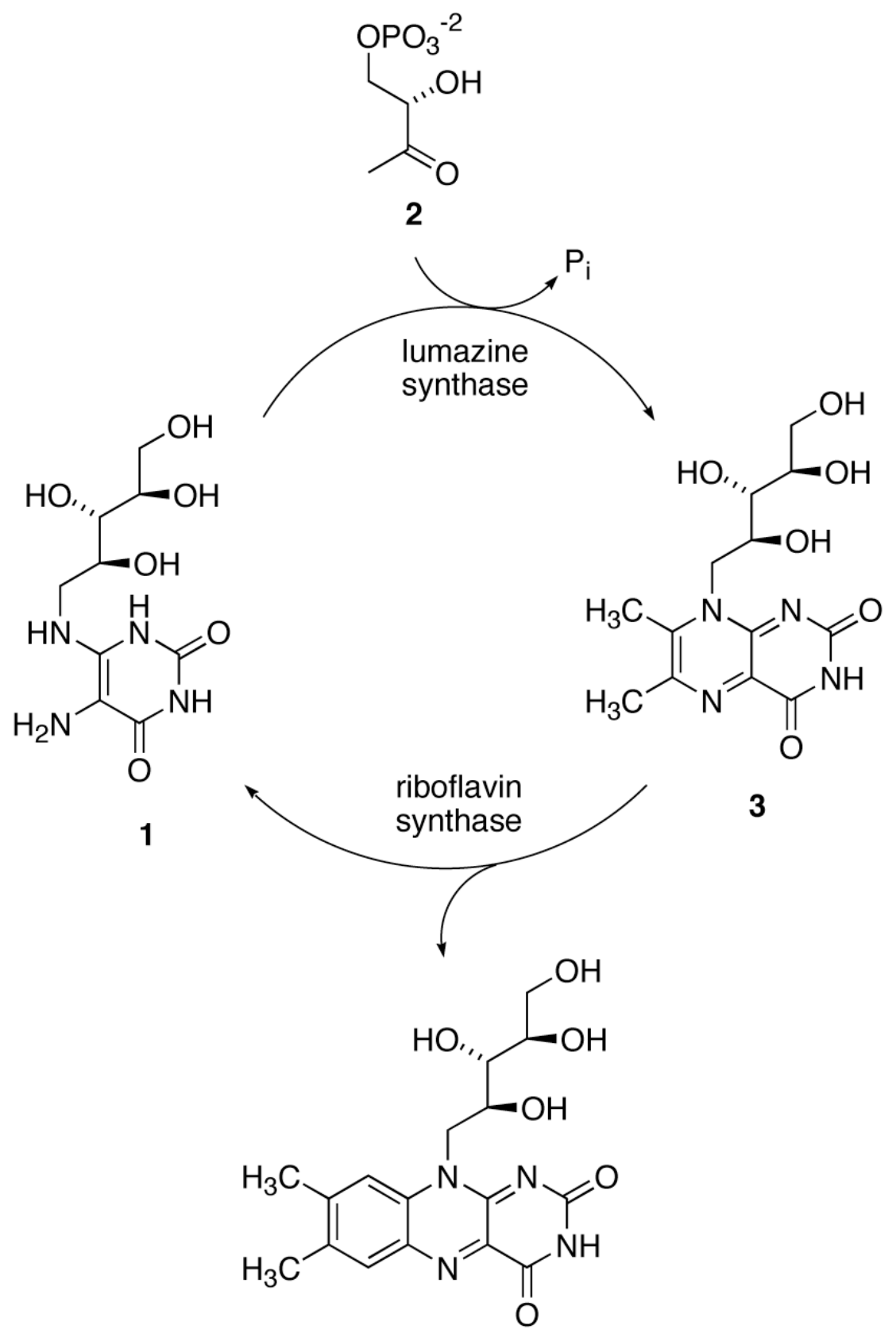

4

SCHEME 1. 


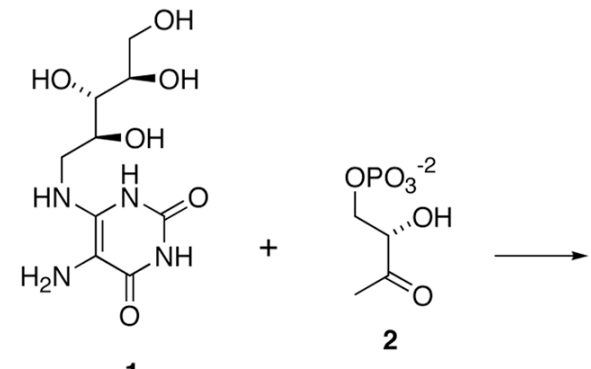<smiles>COP(=O)(O)OC[C@H](O)[C@H](O)Nc1c(NCC(O)C(O)C(O)CO)[nH]c(=O)[nH]c1=O</smiles><smiles>C=C(O)/C(C)=N\c1c(NCC(O)C(O)C(O)CO)[nH]c(=O)[nH]c1=O</smiles><smiles></smiles>

9

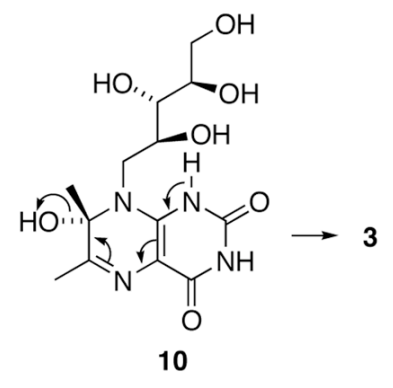

SCHEME 2. 


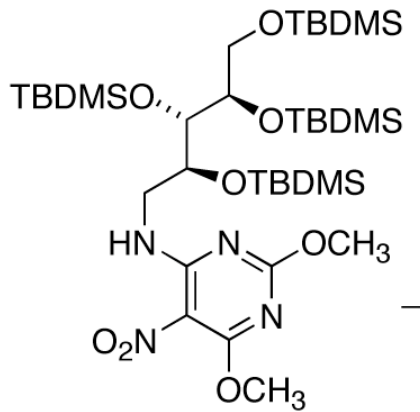

15

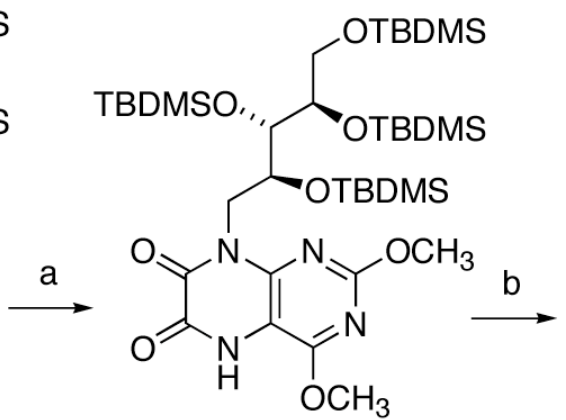

$16(36 \%)$

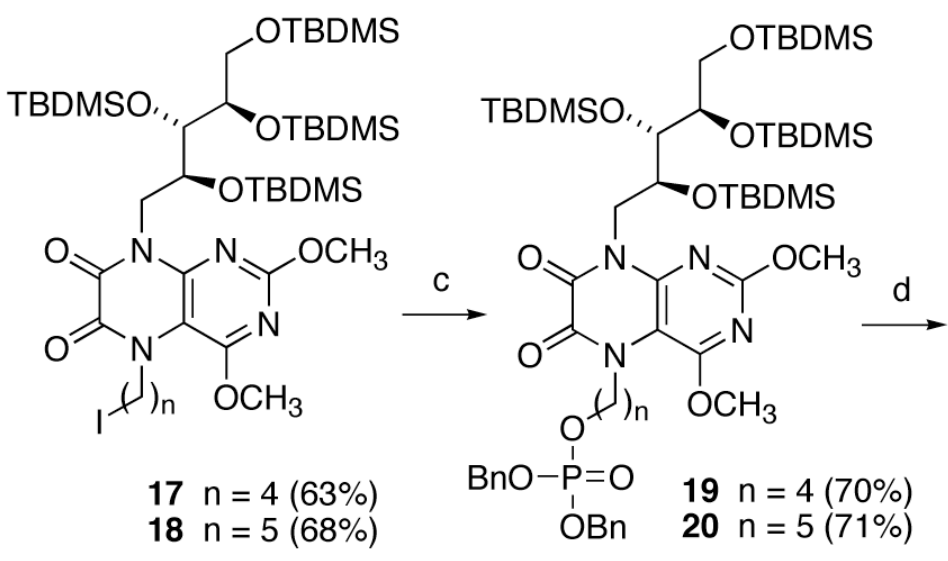

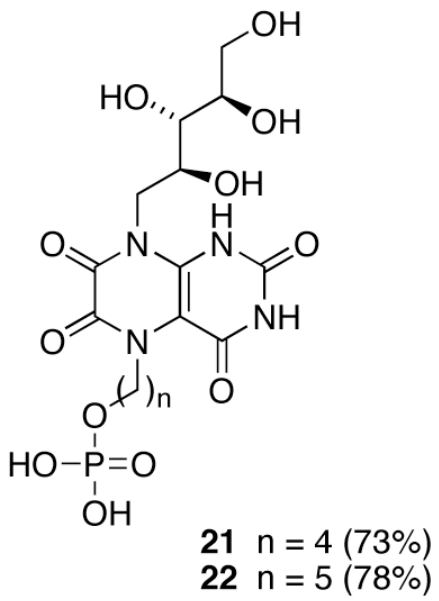

SCHEME 3.

Reagents and conditions: (a) (1) $\mathrm{H}_{2}, \mathrm{Pd} / \mathrm{C}, \mathrm{MeOH}, 23{ }^{\circ} \mathrm{C}$ (3 days); (2) EtOCOCOCl, $\mathrm{Et}_{3} \mathrm{~N}$, $\mathrm{CH}_{2} \mathrm{Cl}_{2}, 0^{\circ} \mathrm{C}\left(10 \mathrm{~h}\right.$ ); (3) $\mathrm{Et}_{3} \mathrm{~N}$, EtOH, reflux (72 h). (b) Diiodoalkane, $\mathrm{K}_{2} \mathrm{CO}_{3}, \mathrm{CH}_{3} \mathrm{CN}$, reflux $(10 \mathrm{~h})$. (c) $\mathrm{AgOPO}(\mathrm{OBn})_{2}, \mathrm{CH}_{3} \mathrm{CN}$, reflux (12 h). (d) $\left[48 \% \mathrm{HBr}-\mathrm{H}_{2} \mathrm{O}(2: 1)\right]-\mathrm{MeOH}(1 ; 1)$, $55-60{ }^{\circ} \mathrm{C}(3 \mathrm{~h})$. 
TABLE 1

Inhibition Constants vs. B. subtilis Lumazine Synthase, M. tuberculosis Lumazine Synthase and E. coli Riboflavin Synthase.

\begin{tabular}{|c|c|c|c|c|}
\hline \multirow[t]{2}{*}{ Compd } & \multirow[t]{2}{*}{ Parameter } & \multicolumn{2}{|c|}{ Lumazine synthase } & \multirow{2}{*}{$\frac{\text { Riboflavin synthase }}{\text { E. } \operatorname{coli}^{c}}$} \\
\hline & & B. subtilis ${ }^{a}$ & M. tuberculosis $b$ & \\
\hline \multirow[t]{3}{*}{14} & $\begin{array}{l}\text { inhibition mechanism } \\
K_{\mathrm{s}}^{d}(\mu \mathrm{M})\end{array}$ & $\begin{array}{c}\text { competitive } \\
6.3 \pm 0.5\end{array}$ & $\begin{array}{c}\text { competitive } \\
250 \pm 43\end{array}$ & $\begin{array}{c}\text { competitive } \\
2.7 \pm 0.2\end{array}$ \\
\hline & $\mathrm{k}_{\mathrm{cat}} e\left(\min ^{-1}\right)$ & $2.6 \pm 0.1$ & $1.1 \pm 0.1$ & $15.0 \pm 0.3$ \\
\hline & $K_{\mathrm{i}}^{f}(\mu \mathrm{M})$ & $7.8 \pm 0.5$ & $1.4 \pm 0.1$ & $0.0062 \pm 0.0005$ \\
\hline \multirow[t]{4}{*}{21} & $\begin{array}{l}\text { inhibition mechanism } \\
K_{\mathrm{s}}(\mu \mathrm{M})\end{array}$ & $\begin{array}{l}\text { mixed } \\
7.1 \pm 1.0\end{array}$ & $\begin{array}{c}\text { competitive } \\
240 \pm 29\end{array}$ & $\begin{array}{c}\text { mixed } \\
2.5 \pm 0.3\end{array}$ \\
\hline & $\mathrm{k}_{\text {cat }}\left(\min ^{-1}\right)$ & $2.1 \pm 0.1$ & $1.2 \pm 0.1$ & $15.0 \pm 0.4$ \\
\hline & $K_{\mathrm{i}}(\mu \mathrm{M})$ & $150 \pm 43$ & $0.036 \pm 0.004$ & $9.7 \pm 4.1$ \\
\hline & $K_{\mathrm{is}}^{g}(\mu \mathrm{M})$ & $400 \pm 130$ & & $21 \pm 5$ \\
\hline \multirow[t]{3}{*}{22} & $\begin{array}{l}\text { inhibition mechanism } \\
K_{\mathrm{s}}(\mu \mathrm{M})\end{array}$ & $\begin{array}{c}\text { competitive } \\
5.8 \pm 0.4\end{array}$ & $\begin{array}{c}\text { competitive } \\
210 \pm 28\end{array}$ & $\begin{array}{c}\text { competitive } \\
2.9 \pm 0.4\end{array}$ \\
\hline & $\mathrm{k}_{\text {cat }}\left(\min ^{-1}\right)$ & $2.7 \pm 0.1$ & $0.99 \pm 0.07$ & $14 \pm 1$ \\
\hline & $K_{\mathrm{i}}(\mu \mathrm{M})$ & $27 \pm 6$ & $0.012 \pm 0.004$ & $0.14 \pm 0.02$ \\
\hline \multirow[t]{3}{*}{23} & $\begin{array}{l}\text { inhibition mechanism } \\
K(\mu \mathrm{M})\end{array}$ & $\begin{array}{c}\text { competitive } \\
3.2 \pm 0.4\end{array}$ & $\begin{array}{l}\text { competitive } \\
63 \pm 6\end{array}$ & $\begin{array}{c}\text { competitive } \\
2.1 \pm 0.2\end{array}$ \\
\hline & $\mathrm{k}_{\mathrm{cat}}\left(\min ^{-1}\right)$ & $3.1 \pm 0.1$ & $1.4 \pm 0.1$ & $17.0 \pm 0.4$ \\
\hline & $K_{\mathrm{i}}(\mu \mathrm{M})$ & $170 \pm 26$ & $0.0041 \pm 0.0023$ & $330 \pm 83$ \\
\hline \multirow[t]{4}{*}{24} & $\begin{array}{l}\text { inhibition mechanism } \\
K(\mu \mathrm{M})\end{array}$ & $\begin{array}{l}\text { mixed } \\
38+04\end{array}$ & competitive & competitive \\
\hline & $\mathrm{k}_{\mathrm{cat}}\left(\min ^{-1}\right)$ & $\begin{array}{c}5.8 \pm 0.4 \\
3.15 \pm 0.10\end{array}$ & $\begin{array}{c}03 \pm 5 \\
1.40 \pm 0.04\end{array}$ & $\begin{array}{c}2.0 \pm 0.2 \\
17.0 \pm 0.4\end{array}$ \\
\hline & $K_{\mathrm{i}}(\mu \mathrm{M})$ & $270 \pm 85$ & $0.0047 \pm 0.0019$ & $2.4 \pm 0.2$ \\
\hline & $K_{\text {is }}(\mu \mathrm{M})$ & $650 \pm 160$ & & \\
\hline
\end{tabular}

${ }^{a}$ Recombinant lumazine synthase of $B$. subtilis.

${ }^{b}$ Recombinant lumazine synthase from M. tuberculosis.

${ }^{c}$ Recombinant riboflavin synthase from $E$. coli.

$d_{K_{\mathrm{S}}}$ is the substrate dissociation constant for the equilibrium $\mathrm{E}+\mathrm{S} \rightleftarrows \mathrm{ES}$.

$e_{\mathrm{k}} \mathrm{k}_{\mathrm{c}}$ is the rate constant for the process $\mathrm{ES} \rightarrow \mathrm{E}+\mathrm{P}$.

$f K_{\mathrm{i}}$ is the inhibitor dissociation constant for the process $\mathrm{E}+\mathrm{I} \rightleftarrows \mathrm{EI}$.

${ }^{g} K_{\text {is }}$ is the inhibitor dissociation constant for the process ES $+\mathrm{I} \rightleftarrows$ ESI. $\mathrm{K}_{\mathrm{i}}$ values of less than $1 \mu \mathrm{M}$ are shown in bold type. 